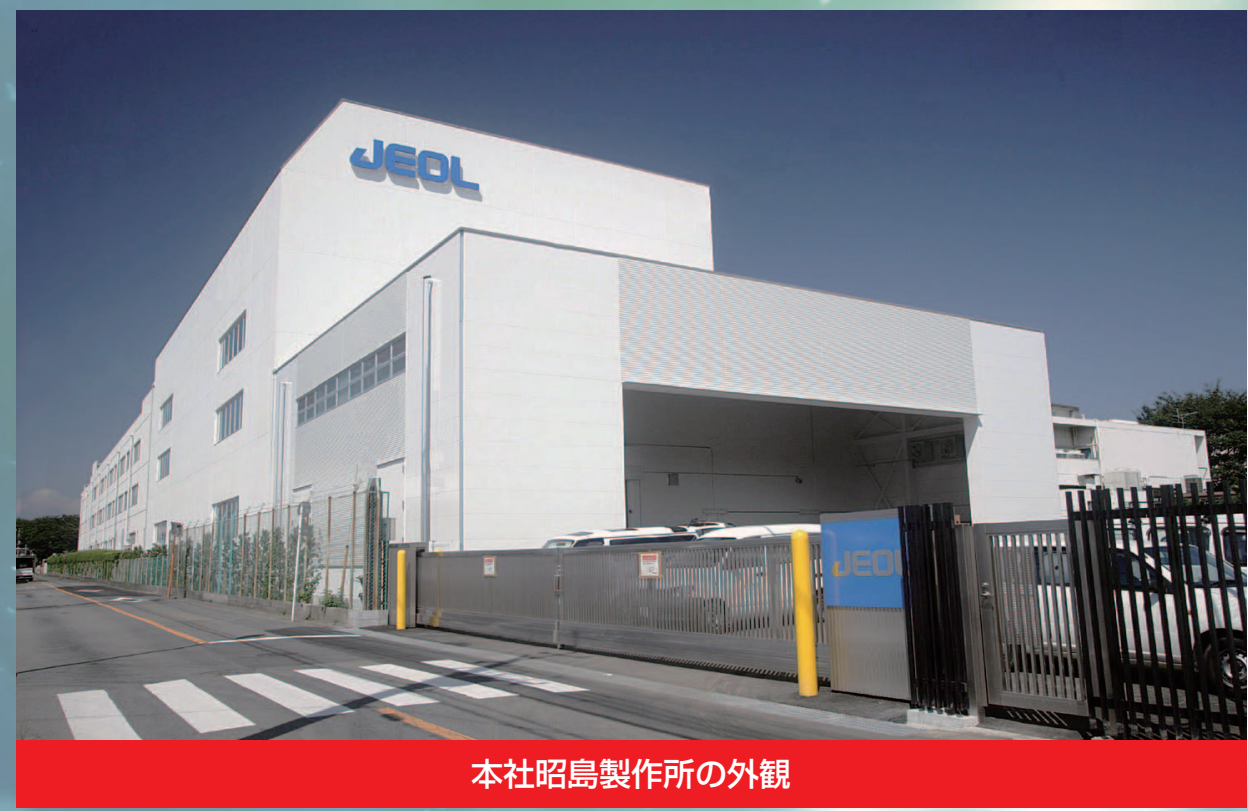

Gravure \& Interview 精密工学の最前線

\title{
最新の電子光学装置が拓く 表面·界面解析技術の現状と将来
}

日本電子株式会社
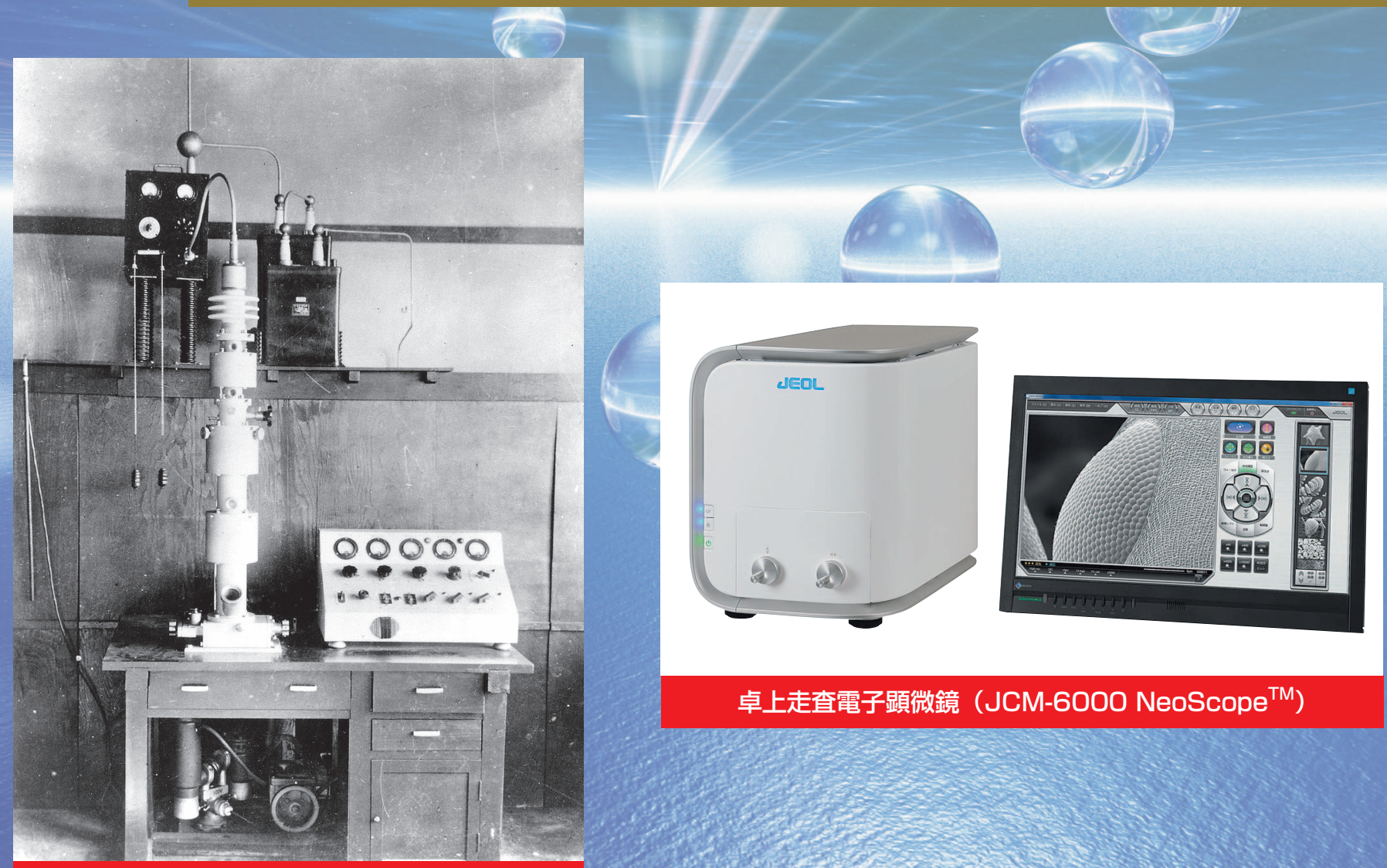

卓上走查電子顕微鏡 $\left(\mathrm{JCM}-6000\right.$ NeoScope $\left.{ }^{\mathrm{TM}}\right)$

商用 1 号機として昭和 22 年に開発された 透過型電子顕微鏡 (DA-1) 
Q 御社の事業や沿革をお教えくだ さい.

弊社の初代社長である風戸健二は, 戦時中に海軍技術研究所電波研究部に 籍を扔いていました。そして，戦後の 日本には電子顕微鏡開発が必要である との信念をもち, 終戦後すぐに電子顕 微鏡の設計を開始し, 昭和 22 年に透 過型電子顕微鏡の 1 号機である「DA-1」 を完成させました.

この成果を踏まえ，風戸は昭和 24 年に弊社を設立しました，設立時の社 名は, (株) 日本電子光学研究所 (Japan Electron Optics Laboratory Co., Ltd.) であり, 英語表記の略称として命名し た JEOL が今日も用いられています。 東京・三鷹市で, 総勢 10 名のス夕ッ フにより透過型電子顕微鏡の生産を開 始しました，その後, 核磁気共鳴装置 (昭和 31 年), 電子プローブマイクロ アナライザ (昭和 37 年), 走査電子顕 微鏡 (昭和 41 年), オージエ電子分光 装置（昭和 49 年）等の表面分析装置を 次々と製品化するとともに，社名も昭 和 36 年に日本電子 (株) と改め, 今日 に至っています。

Q 一言で表面分析といっても，そ の領域は幅広いと思います，御社で手 掛けられている表面分析装置の原理 · 特徵を簡単にご説明いただくととも に，堤様のお仕事についてお話しくだ さい.

弊社は, 分析装置を含む多様な理化 学機器を取り扱っていますが, 表面分 析に関していえば，電子線をプローブ とするものと，X線をプローブとする ものに大別できます

電子線をプローブとするものの代 表格が，弊社の出発点にもなった透 過電子顕微鏡 $(\mathrm{TEM})$ です。これは, $100 \mathrm{kV}$ 以上の電圧で加速した電子を 薄片化した試料 (厚さ数 $100 \mathrm{~nm}$ 以下) に照射し，試料を透過する電子を結像 することにより，構造を観察する顕微 鏡です，後でも述べますが，今では空 間分解能が原子レベルにまで到達して

\section{最新の電子光学裝置が砳く表面・界面解析技術の現状と捋来}

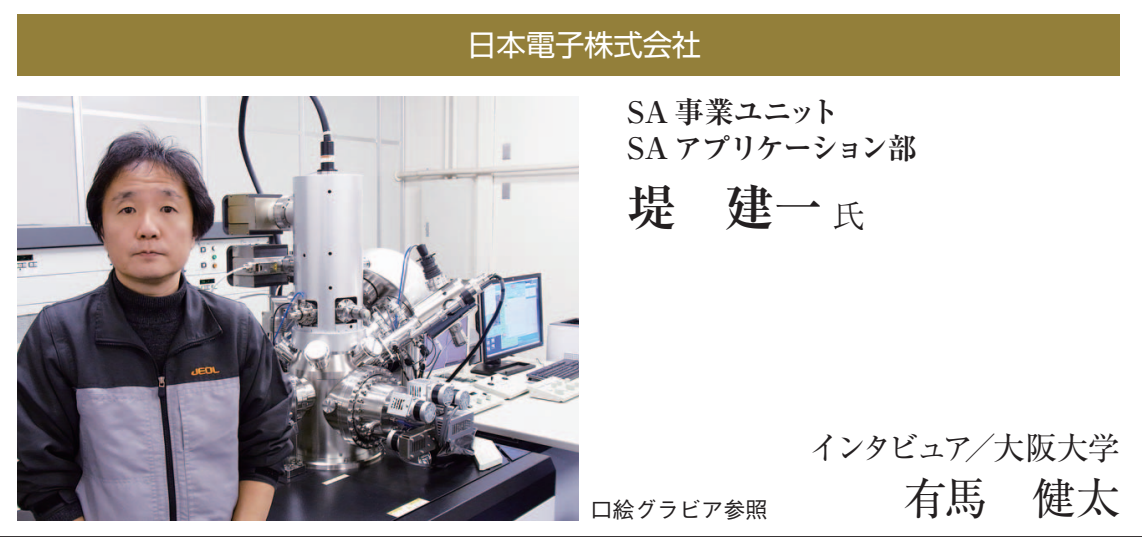

います。それに対して走査電子顕微鏡 (SEM) は, 数十 $\mathrm{kV}$ 以下の比較的小さ い電圧で加速した微小電子線により, バルク試料の表面を走査し, 表面から 放出される二次電子や反射電子を検出 器で受け, それらの強度をマッピング するものです，試料を薄層化すること なく, 最表面の微細な構造を可視化で きます。

また, 試料表面に電子線を照射する と, 表面を構成する元素固有のエネル ギーをもつ特性 X 線やオージェ電子 が放出されます。これらを検出するこ とにより，表面から $1 \mu \mathrm{m}$ 程度までの 試料表面の元素分析（電子プローブマ イクロアナライザ：EPMA）や，最表 面 (約 $6 \mathrm{~nm}$ ) 領域での微量元素分析お よび化学状態分析 (オージェ電子分析: AES）が実現できます。一方で，X 線 をプローブとするものの代表格として は, X 線光電子分光 (XPS) が挙げら れます。

私は現在，AES およびXPSに関す る装置開発と応用分析に携わっていま す.

Q 本記事のタイトルとして,『表面』 ではなく，『表面・界面』解析技術と あります．界面解析技術の最前線をお 話しください.

表面分析装置のアプリケーション といえば，いわゆる何も前処理を行わ ない試料表面が分析対象になると思 われがちですが，実際にはいろいろな
処理を施すことで，試料の表面を覆つ ている薄膜の性質や，その薄膜と基板 との界面を評価する分析例の方が多 いです.

界面を表面分析装置で分析するため には，あらかじめ界面を露出させる必 要があります，従来から，Arイオン によるエッチングを利用し，試料内部 の界面を露出させる手法はよく知られ ています。これと, XPSやAES といっ た表面分析とを交互に繰り返すことに より, 元素分析や化学結合状態に関す るデプスプロファイルを得ることがで

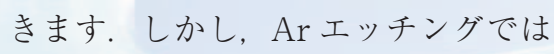
原子のノッキング現象に代表されるよ うな物理的ダメージ，あるいは選択 エッチングが生じ, 本来の界面状態を 変化させてしまう場合があります。

これらのダメージの影響を回避す る目的で，機械研磨などで断面を作製 し，断面方向から試料を分析する方法 があり，界面分析においてはこちらが 主流であるともいえます，しかし実際 には,この手法を用いた場合にも，形 成した断面に物理的なダメージが入っ てしまいます，例えば，一般的なダイ ヤモンドペーストやコロイダルシリカ を用いて研磨した場合には，それぞれ $100 \mathrm{~nm}$ や $10 \mathrm{~nm}$ オーダーの加工変質 層が導入されてしまいます，界面分析 の前処理として行う研磨プロセスによ り加工変質層が形成されてしまうと, その後に行う表面敏感な断面観察にお いて，何を計測しているのか分からな くなってしまいます。 
弊社では 2003 年に, Arイオンを試 料断面に平行に入射するクロスセク ション・ポリッシャーと呼ばれる断面 作製装置の開発に成功しました。これ により, 加工変質層がほとんどなく, ポリッシング後の後処理も一切不要な 断面作製が可能になりました.今では, 界面における元素分析や化学状態分析 を高い信頼性の下で計測できる態勢が 整ったといえます。

Q 界面を正しく評価するためには， 界面を露出させるための加工技術が鍵 になるとのお話が印象的でした.では, 本学会の会員にもなじみ深い TEM や SEM に関する技術動向をお聞かせく ださい.

現在ではすでに，原子レベルの空間 分解能をもつ TEM J JEM-ARM200F」 が完成しています。これは，照射系球 面収差補正装置を標準搭載し, 機械的. 電気的安定度を極限まで高めることに より実現できます。冷陰極電界放出形 電子銃から出る電子プローブの球面収 差を完全に補正することにより，走 査透過像として世界最高の空間分解能 (78 pm) を保証するまでになっていま す。またこの電子銃は, 従来の電界放 出形電子銃を用いた場合と比して, 一 桁以上の高い電流密度を得ることがで きます。そのため，原子レベルでの元 素分析が可能となるとともに, 測定時 間が大幅に短縮されました。また, “走 查透過環状明視野像”と呼ばれる測定 モードを用いることにより，Liに代表 される, 結晶試料中の軽元素の原子位 置を直接観察することが可能になりま した。

SEM に関していえば近年, 電子線 源にショットキー型電界放射電子銃を 搭載した高空間分解能を有する SEM が開発され，検出方法も，試料へのバ イアス印加方式を用いる“ジェントル ビーム方式”によって，高い空間分解 能と試料最表面の微細構造観察を両立 することが可能になりました. SEM は，入射電子線を絞るために高い加速 電圧 (数 $10 \mathrm{kV})$ を必要とします。一方
で，脱出深さの小さい放出電子で結像 させなければ，試料最表面を観察する ことができません，そのため，入射電 子線のエネルギーを低く設定する必要 があります。私たちは，入射電子に対 して減速の作用をもたらすバイアス電 圧を試料に印加し，低い試料到達エネ ルギー (最小 $10 \mathrm{eV})$ においても，高分 解能でシグナル / ノイズ比が高い画像 を得ることに成功しました。また，二 次電子や反射電子を取り込むための 4 種類の検出器を搭載した新型の FESEM「JSM-7800F」が開発され, 試料 表面の局所的な密度差や凹凸構造，結 晶方位の分布等を選択的に強調して可 視化できるようになりました。一方で, 上記のようなハイエンド型の SEM と は対照的に, 卓上に設置でき, 操作も 容易なベンチトップ型の SEM も開発 しています。通常は外見がいかめしい SEM ですが, この SEM 本体の外観は, 有名なデザイン事務所である $\mathrm{KEN}$ OKUYAMA DESIGN により設計され ました。真空装置とは思えない曲線型 のフォルムに特徵があります。研究. 教育現場において, 光学顕微鏡を扱う ような感覚で使っていただければと思 います。

Q TEM や SEM に関して, 今も日 進月歩で技術開発が進んでいる様子が よく分かりました. 特に, 顕微鏡と名 付けられているものの，単に『観る』 だけでなく，観ているものを『分析す る』という要求が高まっていることも 感じ取れました.

では, 御社の海外戦略および, 海外 同業者と比べた技術的な強みについて お聞かせください.

弊社は,「創造と開発」を合言葉に, 長年にわたって多くの電子光学装置を 世に送り出してきました.したがって, 表面分析装置に関して世界最高水準の 技術力を有しています。しかし，弊社 の強みはそれだけに留まりません，先 にも述べましたように，分析は“総合 力”を必要とします、すなわち，分析 対象となる試料の前処理, 一電子線や X
線をプローブとした画像や分光スペク トルの取得, 得られた結果の解析の全 てが備わって, 初めて意味のある結果 が得られます。弊社は, 装置を納入す るだけでなく，トータルでお客様が知 りたいというニーズを満足させる技術 を提供することができます。これは， 私たちの大きな強みであると考えてい ます.

また弊社では, 国内外の研究機関と 積極的に産・官・学連携に取り組み, 次世代に必要とされる表面分析装置を 他社に先駆けて開発する態勢を整えて います。2000年以降に限っても，東 京大学, 九州大学, 独立行政法人 産 業技術総合研究所, オックスフォー ド大学 (英国), シカゴ大学 (米国) 等, 連携先は多岐にわたっています。

\section{$\mathbf{Q}$ 次に, 堤様が考える未来の表面・ 界面分析の姿についてお話しください.}

ユーザーの方とお話をしていると， 分析の世界はすでに十分に成熟してお り，手法を組み合わせればあらゆる情 報が手に入るとお考えの方が多い印象 を受けます。しかし私から見ると，表 面分析技術は全く成熟しているとはい えません，例えば，AESやXPS スペ クトルを測定すると, 化学状態の変化 によるスペクトルの形状変化やピーク シフトが頻繁に現れます。また，試料 作製から測定に至るまでの污染や加工 変質層の混入により, スペクトル形状 は当然変化します。加えて, 定量分析 を行うための理論的な前提条件も, 完 全であるとはいい難いです。したがっ て, 測定対象試料が同じであっても, 解析者の数だけ解析結果が異なると いう事態が頻繁に起こります。弊社で は, 全ての表面分析装置に関して, 誰 が行っても同じ実験データ, 同じ解析 結果が出せるように, 現行装置の改良, さらには先にも触れた, 分析における “総合力”を向上させるべく，日々取 り組んでいます。

Q 最後に, 精密工学会の会員へメッ セージをお願いします. 


\section{Gravure \& Interview 精密工学の最前線}

お客様の試料を分析していると，そ の精密加工技術の進歩は目を見張るも のがあります，私には，加工技術と分 析技術は競い合っているように見えま す，精密加工技術が進歩して，より理 想的な表面・界面が形成できれば，そ れを評価するための分析装置が必要と なり，私たちの出番となります。この
繰り返しで，表面分析装置が発展して きました，皆様ともよい意味で，共に ライバルとなるような関係が築ければ と思います。また，もし今お手元に， 難しくて測定を諦めておられるような 試料があれば，お気軽にご相談くださ い，何らかのお手伝いができるかもし れません，今後ともよろしく扮願いい
たします

堤様，本日はご多用のところ，表面・ 界面解析技術に関する最新動向をお話 しいただき，誠にありがとうございま した.

(a) ダイヤモンド砥粒 （直径 $1 \mu \mathrm{m} ）$ を用 いた研磨の場合

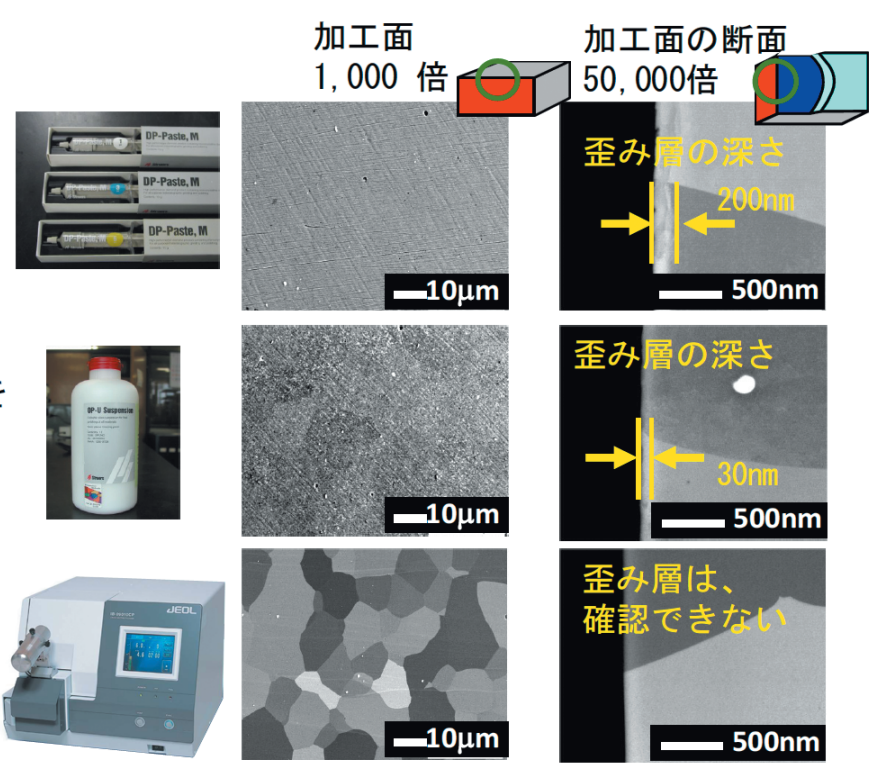

(b) コロイダルシリカを 用いた研磨の場合

(c) 開発したクロスセ クション・ポリッ シャ (IB-09010CP /09020CP) を用い た場合

界面分析に必要な断面形成のための加工法の比較
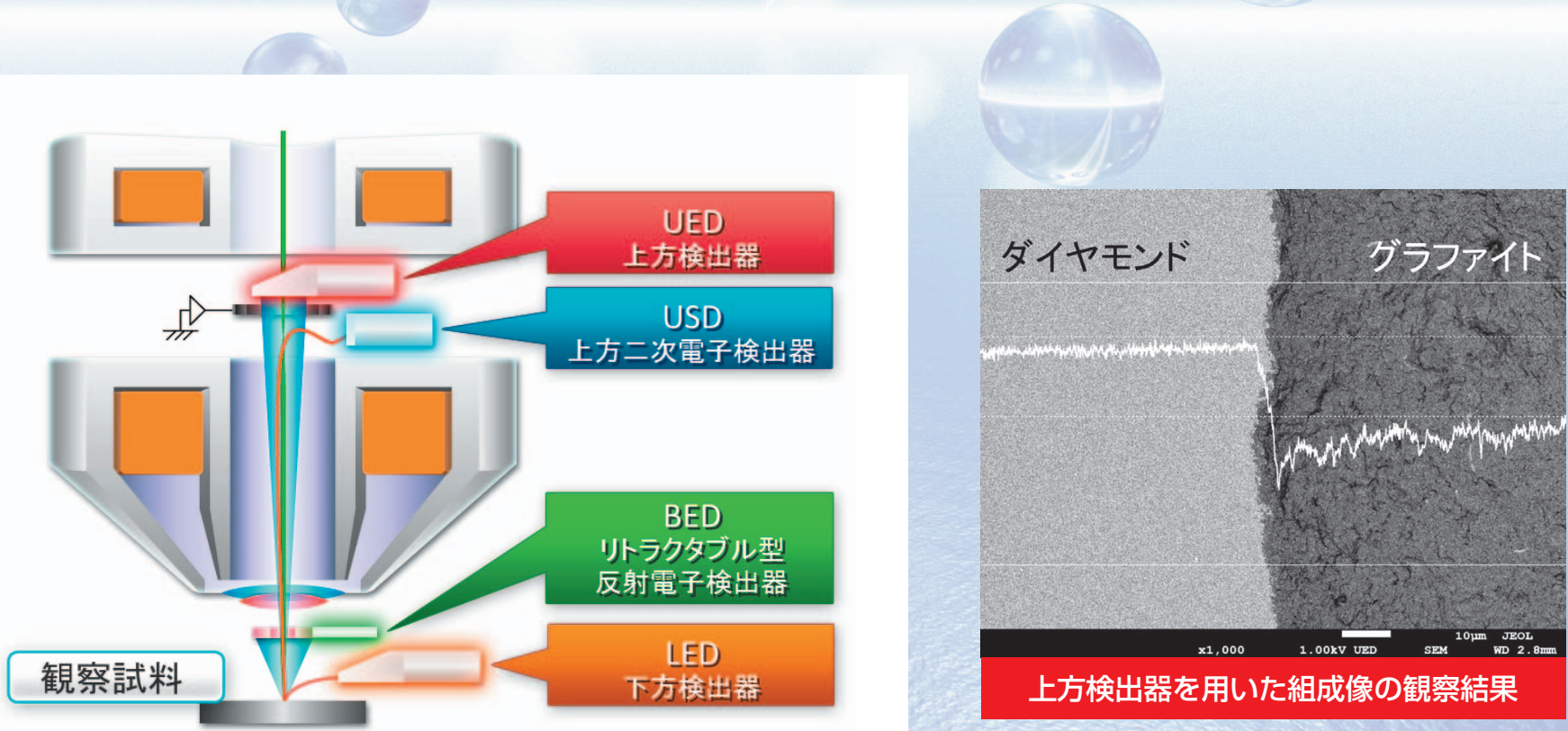

走查電子顕微鏡（JSM-7800F）に組み込まれた4種類の電子検出器

428 精密工学会誌/Journal of the Japan Society for Precision Engineering Vol.80, No.5, 2014 